\title{
An evaluation of surface temperature distribution under different charging and discharging modes of the lithium- ion phosphate battery using Thermal Imaging
}

\author{
*Pathmanaban P1, Gnanavel B.K², Shanmuga Sundaram Anandan ${ }^{3}$, \\ Chermadurai $S^{4}$
}

\author{
${ }^{1}$ Assistant Professor, Department of Automobile Engg, Velammal Engineering College, \\ Chennai, India, \\ ${ }^{2}$ Subject Matter Expert-Mechanical, Larsen and Toubro Limited - Construction Campus, \\ Chennai, India, \\ ${ }^{3}$ Professor and Head, Sree Sastha Institute of Engineering and Technology, Chennai, India, \\ ${ }^{4}$ Chermadurai S, Assistant Professor, Velammal Engineering College, Chennai, India \\ ${ }^{1}$ princepathu@gmail.com, ${ }^{2}$ gnanavelbk@gmail.com, ${ }^{3}$ speakdrss@gmail.com, ${ }^{4}$ \\ chermadurai@velammal.edu.in
}

\begin{abstract}
:
This study aims to determine the thermal behavior of lithium-ion phosphate (LiFePO4) 20Ah battery by Thermal imaging. This study focuses on day/night charging and discharging to the battery's temperature distribution. The thermal gradient of battery, LiFePO4 powered bike at different speeds $30 \mathrm{kmph}, 40 \mathrm{kmph}, 50 \mathrm{kmph}$ both load and without load condition. The spatial distribution of LiFePO4 cells was not stable during the discharging process. No significant temperature rise was recorded at the end of the discharge. During the range test at 30kmph, $40 \mathrm{kmph}$, and 50kmph, the maximum surface temperature reached $47.90^{\circ} \mathrm{C}, 44.20^{\circ} \mathrm{C}$, and $46.70{ }^{\circ} \mathrm{C}$, respectively. The battery's front view was most of the highest surface temperature region. The result shows thermal imaging is an effective tool to predict the temperature behavior of batteries and provide a better thermal management system in battery development.
\end{abstract}

Keywords: $\quad$ LiFePO4 Battery, Thermal Imaging, E-bike, Battery Thermal Management

\section{Introduction}

Global energy conservation concern has focused on electric vehicle technologies (EVs) in the automotive sector necessitate the development of improved rechargeable energy storage systems that are both high in performance and safe[1] [2]. Lithium-ion polymer, LiFePO4 batteries are more sophisticated rechargeable lithium-ion batteries. As an ion transport medium, gel polymer electrolyte is utilized instead of liquid electrolyte. The batteries operate on the same concept as Li-ion batteries and have the same high energy/power density[3]. Because of these benefits, lithium-ion batteries are present the most promising powering solution for sustainable electric road transportation. However, EV development needs high charging, for quick charging and discharging speeds, for increased acceleration. To Increase in current during the charging and discharging causes non-uniform temperature distribution. Besides, 
excessive and uncontrolled heat may lead to thermal runaway and even battery explosion. Therefore, understanding the thermal behavior of energy storage is also essential before developing a battery thermal management system (BTMS) and focusing on monitoring and optimizing the operating temperature of energy storage. Even though the validation process is relatively complex and demanding, Thermal modeling is one of the well-established approaches in researching the thermal behavior of cells [4], [5]. Comparing cell surface temperature is proposed for less complexity and quick confirmation[6],[7]. Single point measurement uses a thermocouple/thermistor to monitor the cell surface temperature, as proven by[8]. Unfortunately, this approach is insufficient for measuring the non-uniform temperature distribution in space [9]. Thermal imaging can measure the distribution in real-time with high accuracy compared to other temperature measuring instruments like thermocouples or thermistors. The thermal imaging camera captures infrared IR rays emitted by a cell and converts them into an electronic signal, then it converted to a thermal image or video [10]. A recent study on the surface temperature distribution of LiPo batteries using thermal images and thermocouples at varied discharge rates produces promising results. The value and position of the highest surface temperature are determined based on the pictures taken in IR. TI max and thermocouple, TC max data used to Achieve the ultimate maximum surface temperature.

This study also examined the temperature rise and surface temperature development at Various discharge rates ranging from $2.0 \mathrm{~A}$ to $10.0 \mathrm{~A}$. The results are presented based on surface temperature distribution, maximum surface temperature, temperature rise evolution, and experimental uncertainty. It concluded that thermal imaging is an effective method for battery thermal management than any other method[11]. Furthermore, the thermal runaway behavior of the LiFePO4 battery during penetration was studied. The result shows the temperature rise depends on penetration depth and high-temperature rise location identified near to positive and negative of the battery [12]. Temperature monitoring of batteries is an effective way of the battery management system. It includes battery temperature, temperature rise rate, and sudden change of temperature[13]. The Li-ion battery module operating temperature and the temperature fluctuation affect the operational temperature. The temperature fluctuation between the batteries greatly influences the Battery's working concerning its life cycle, operating limit, and safety[14]. In connection with previous research, present the work focus on the real-time evaluation of the temperature behavior of the LiFePO4 Battery used in an electrically powered two-wheeler. Since the advantage and reliable results of using a thermal imaging system, the battery test is carried out in the different environmental charging and discharging conditions. Throughout this experimentation, the thermal imaging camera evaluates the temperature behavior of LiFePO4. To the best of the author's knowledge, there is no previous work on $\mathrm{LiFePO} 4$ batteries in this perspective.

\section{MATERIALS AND METHODS}

The experiment was performed on selected commercial packs. Lithium-ion phosphate batteries. Charging day/night, discharging, load/no-load condition. The LiFePO4 contains nine parallel thirteen series Cell units used throughout the experiments. Fig 1 shows the flowchart of the entire experimental procedure. Tables $1 \& 2$ summarize the different properties of the 
tested LiFePO4 cells and other Lithium-ion cells. The battery was fixed in a movable bench to charge, and the battery surface temperature was recorded.

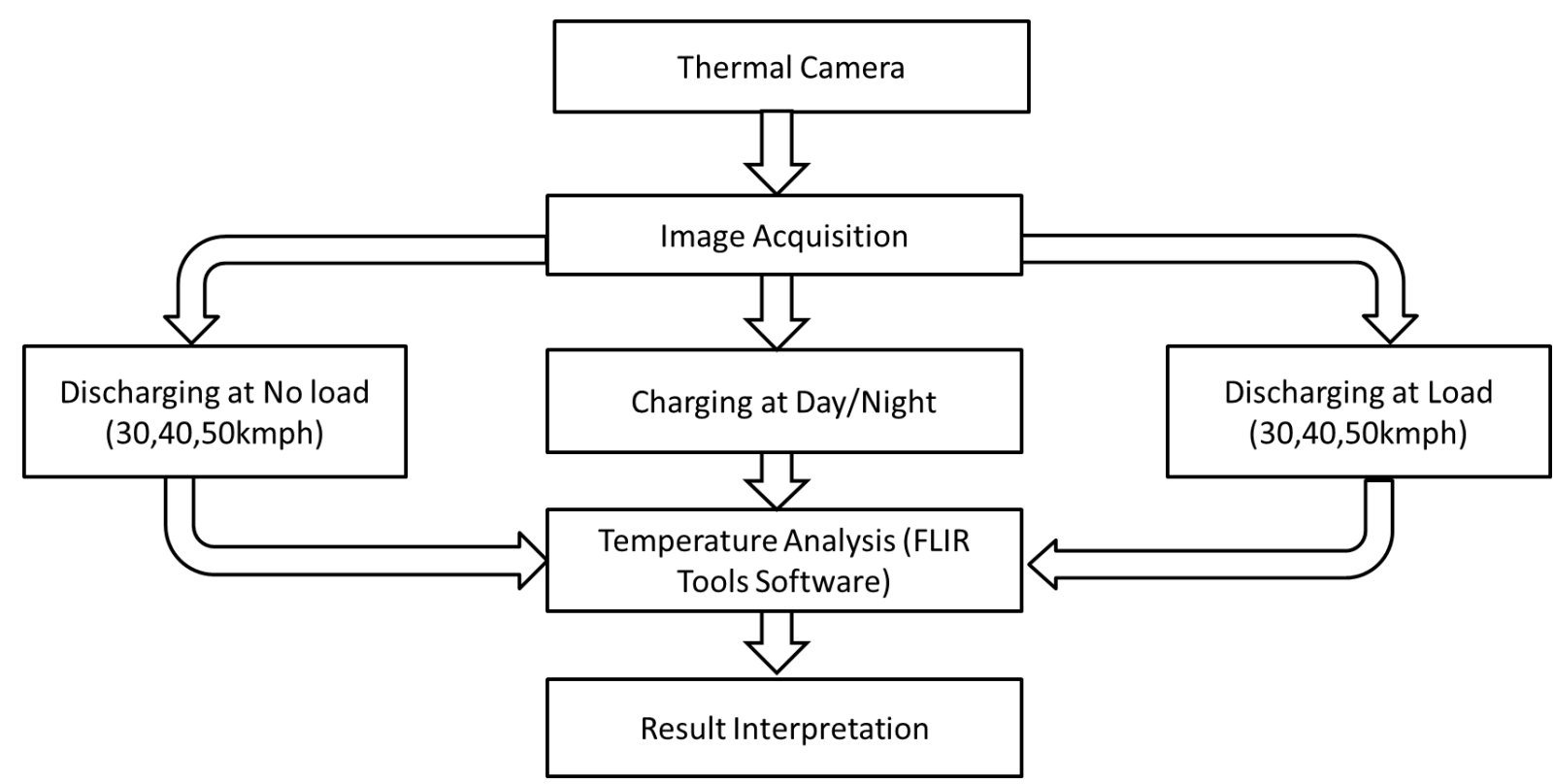

Figure 1. Methodology

Fig 2 shows the arrangement of various components of the experiments; It comprises LiFePO4 cells, the thermal imaging camera, the dry bulb temperature, the relative moisture sensor, and the black carton. The cells surface achieved a thermal equilibrium with the controlled testing condition. Ensure that the cells were initially fully charged and kept on standby mode for 1 hour. A direct current of 10.0 A was used to charge the cells during the Charging. The testing environment was observed and measured by the sensor HTC-2 with $-500^{\circ} \mathrm{C}$ to $70{ }^{\circ} \mathrm{C}$ and 10 to 99\% - RH accuracy. The cells were fully charged based on constant current CC - constant voltage $\mathrm{CV}$ to perform day and night charging. The same charging procedure was applied in the entire experiment. The cut-off voltage was set to $6 \mathrm{~V}$. The battery was left idle for 1 hour until it reached full charge volt of $54.6 \mathrm{~V}$; once the battery surface achieved an equilibrium state with the surrounding temperature, discharging test was also initiated. The exact process followed on the whole testing. A specially designed Electric Bike was used to test the discharging rate of the battery and temperature distribution. The thermal imaging camera, FLIR one Pro, the precision degree is $3.0^{\circ} \mathrm{C}$, was used to take radiation images of the LiFePO4 cells every 3 minutes on the surface, front, right, left, and back views. 

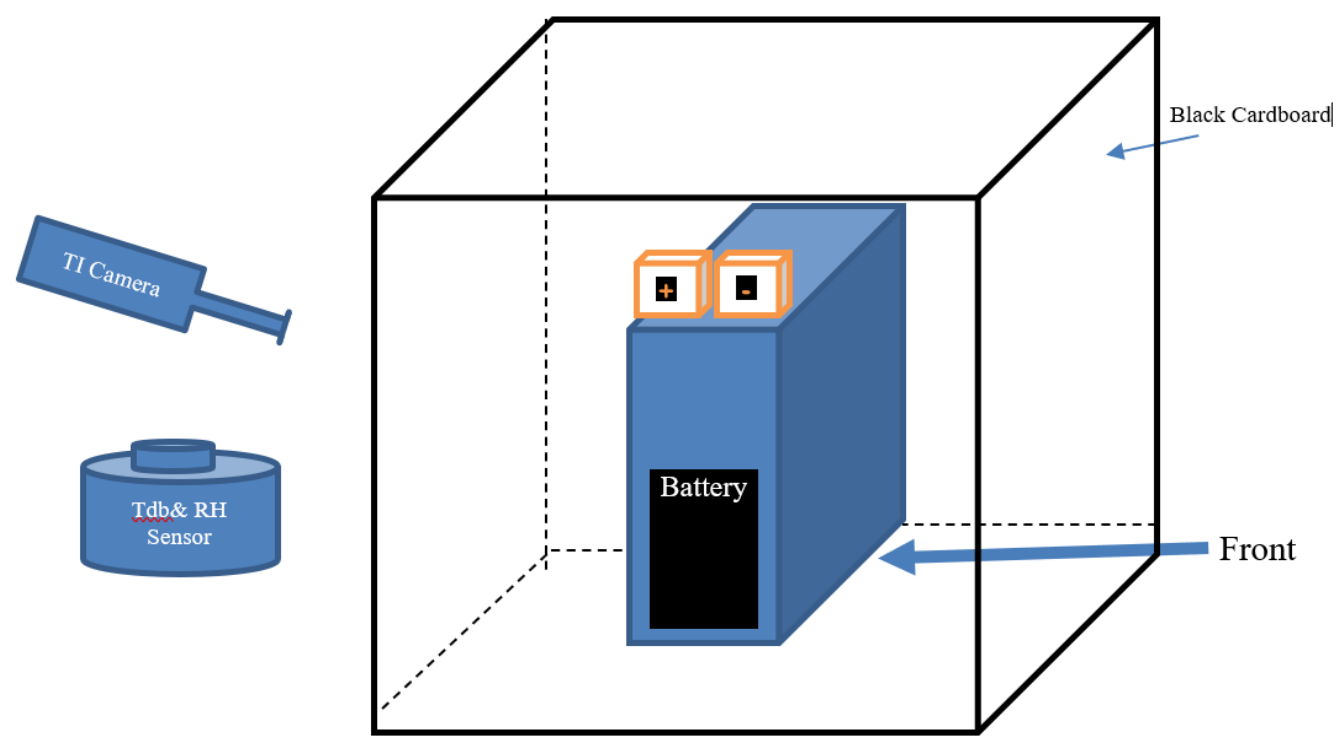

Figure 2. Illustration of Experimental setup

The time for each picture and each side was assigned $25 \mathrm{~s}$. The emissivity of the surfaces of LiFePO4 cells was an average of 0.95 . The division between the characters of the cells and the camera's front lens was $0.5 \mathrm{~m}$.

Table 1. Properties of tested LiFePo4 cells.

\section{Mechanical properties}

Values

\begin{tabular}{|c|c|}
\hline Bodypack & \\
\hline Cell unit & 9 parallel 13 series (117 in total) \\
\hline Size & $260 \mathrm{~mm} \times 170 \mathrm{~mm} \times 70 \mathrm{~mm}$ \\
\hline Net weight & $8 \mathrm{Kg}$ \\
\hline Chemical properties & Descriptions \\
\hline Anode material & Graphite \\
\hline Cathode material & Lithium ferro phosphate \\
\hline Electrolyte material & lithium perchlorate \\
\hline Electrical properties & Values \\
\hline Nominal voltage & $3.6 \mathrm{~V}$ \\
\hline Full charge voltage & $54.6 \mathrm{~V}$ \\
\hline Nominal capacity & $20 \mathrm{Ah}$ \\
\hline Specific energy & $90-120 \mathrm{Wh} / \mathrm{kg}$ \\
\hline Energy density & $325 \mathrm{Wh} / \mathrm{L}$ \\
\hline
\end{tabular}

The thermal energy emission was measured and quantified by the cells to monitor the surface temperature. The camera will achieve a thermal sensitivity below $0.06^{\circ} \mathrm{C}$ or a temperature difference equal to the noise equivalent, NETD of more minor than $70 \mathrm{mK}$. 
Table 2 Properties of various Lithium-ion batteries

\begin{tabular}{|c|c|c|c|c|c|}
\hline Name & $\begin{array}{l}\text { Abbreviatio } \\
\text { n }\end{array}$ & Positive Electrolyte & $\begin{array}{l}\text { Negative } \\
\text { Electrolyte }\end{array}$ & $\begin{array}{l}\text { Cell } \\
\text { Voltage } \\
\text { (V) }\end{array}$ & $\begin{array}{l}\text { Energy } \\
\text { Density } \\
(\mathrm{Wh} / \mathrm{Kg})\end{array}$ \\
\hline $\begin{array}{ll}\text { Lithium } & \text { ion } \\
\text { phosphate } & \end{array}$ & LFP & LiFePO4 & Graphite & $3.2-3.3$ & 130 \\
\hline Lithium cobalt oxide & $\mathrm{LCO}$ & $\mathrm{LiCoO}_{2}$ & Graphite & $3.7-3.9$ & $\begin{array}{l}150 \\
\mathrm{~mA} / \mathrm{kg}\end{array}$ \\
\hline Lithium nickel oxide & LNO & $\mathrm{LiNiO}_{2}$ & Graphite & 3.6 & 150 \\
\hline $\begin{array}{l}\text { Lithium nickel cobalt } \\
\text { aluminum oxide }\end{array}$ & NCA & $\begin{array}{l}\mathrm{Li}\left(\mathrm{Ni}_{0}, 85 \mathrm{Co}_{0}, 1 \mathrm{Al}_{0}, 0\right. \\
5 \mathrm{O}_{2}\end{array}$ & Graphite & 3.65 & 130 \\
\hline $\begin{array}{ll}\text { Lithium } & \text { nickel } \\
\text { manganese } & \text { cobalt } \\
\text { oxide } & \end{array}$ & NMC & $\begin{array}{l}\mathrm{Li}\left(\mathrm{Ni}_{0}, 33 \mathrm{Mn}_{0}, 33 \mathrm{Co}_{\mathrm{o}}\right. \\
33) \mathrm{O}_{2}\end{array}$ & Graphite & $3.8-4.0$ & 170 \\
\hline $\begin{array}{l}\text { Lithium manganese } \\
\text { spinel }\end{array}$ & LMO & $\mathrm{LiMn}_{2} \mathrm{O}_{4}$ & Graphite & 4 & 120 \\
\hline Lithium titanate & LTO & LMO, NCA & $\mathrm{Li}_{4} \mathrm{Ti}_{5} \mathrm{O}_{12}$ & $2.3-2.5$ & 85 \\
\hline
\end{tabular}

The discharging test battery was connected with an electric bike and ran at different speeds until fully discharged at $30 \mathrm{kmph}, 40 \mathrm{kmph}$, and $50 \mathrm{kmph}$. During this test, E-bike kept on its center stand. In addition to that range test was also conducted. The battery is fixed in a particular arrangement made on the bike. At a speed of $30 \mathrm{kmph}$ for every $3 \mathrm{~km}$ range, the image of the battery was taken. This process continues until the complete discharge. The same test was performed at $40 \mathrm{kmph}$ and $50 \mathrm{kmph}$ speeds. The bike was operated by a rider weighing $63 \mathrm{~kg}$ with a pillion weighing $60 \mathrm{~kg}$ during the trial. During this test, friction losses of moving parts and road traction are neglected. For all the test conditions, twenty sets of images were captured. Each group comprises four images containing pictures of the battery's front, right, left, and backside. FLIR tools application was used to extract the temperature readings from captured images.

\section{RESULT AND DISCUSSION}

Thermal images of the battery taken at various charging and discharging conditions are analyzed, and temperature distributions have been extracted. All the images of the LiFePO4 battery were grouped into four different views, and temperature distributions are highlighted in Fig. 5. A red triangle in the images indicates the maximum surface temperature. 
Table 2 Average surface temperatures of different charging and discharging conditions

\begin{tabular}{cccccc}
\hline Status & & Front & Right & Back & Left \\
\hline \multirow{2}{*}{ Charging } & day & 37.23 & 35.69 & 37.19 & 34.89 \\
& Night & 35.63 & 33.89 & 35.29 & 33.00 \\
Discharging & 30 Kmph & 32.05 & 31.78 & 31.96 & 31.00 \\
(without load) & $\mathbf{4 0 K m p h}$ & 31.89 & 31.39 & 31.71 & 31.00 \\
& $\mathbf{5 0 K m p h}$ & 32.33 & 31.95 & 32.25 & 32.00 \\
Discharging (with & $\mathbf{3 0 K m p h}$ & 42.84 & 39.75 & 42.40 & 40.00 \\
load) & $\mathbf{4 0 K m p h}$ & 38.55 & 38.36 & 38.34 & 38.00 \\
& $\mathbf{5 0 K m p h}$ & 38.72 & 37.01 & 38.69 & 36.50 \\
\hline
\end{tabular}

The testing environment was maintained at a temperature, $28.5+-0.7{ }^{\circ} \mathrm{C}$ and relative humidity $\mathrm{RH}=71.9+-0.8 \%$ throughout the experiments. During charging at daytime, the average surface temperature of the battery was recorded as $36.40^{\circ} \mathrm{C}$, and the highest temperature was $40.50^{\circ} \mathrm{C}$. The highest temperature was obtained at the front side of the lithiumion phosphate battery. Fig 3(a) The IR image's spatial temperature distribution indicates that the temperature gradient was distinctive at various discharge times. At the start of the discharge operation, the surfaces of batteries were uniformly distributed in all discharging conditions. During night charging, $34.67^{\circ} \mathrm{C}$ and $38.90^{\circ} \mathrm{C}$ were average temperatures and maximum temperatures.

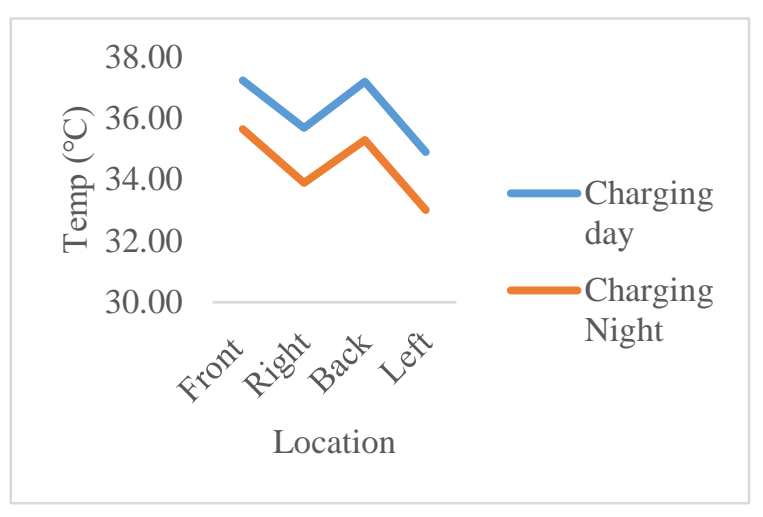

Figure 3(a)

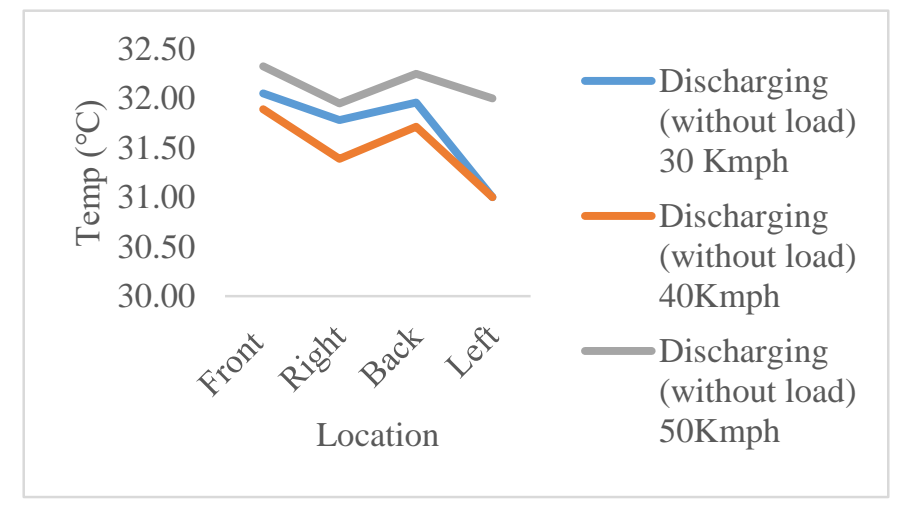

Figure 3(b) 


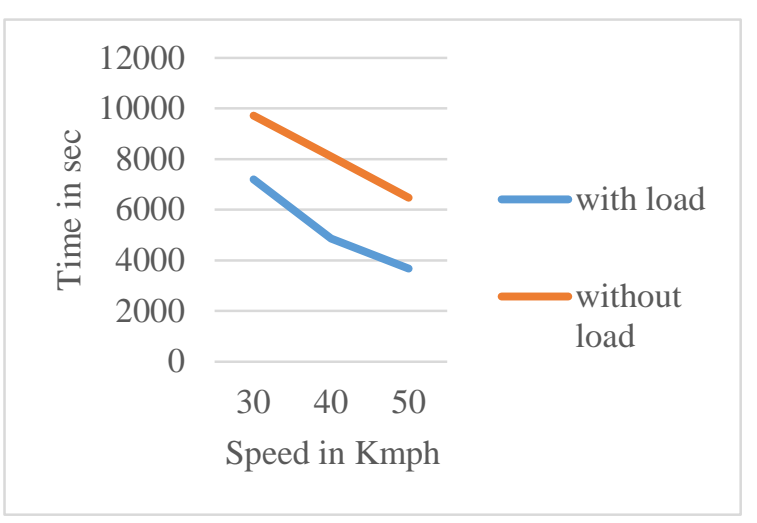

Figure 4.Time Vs speed(load \& No load)

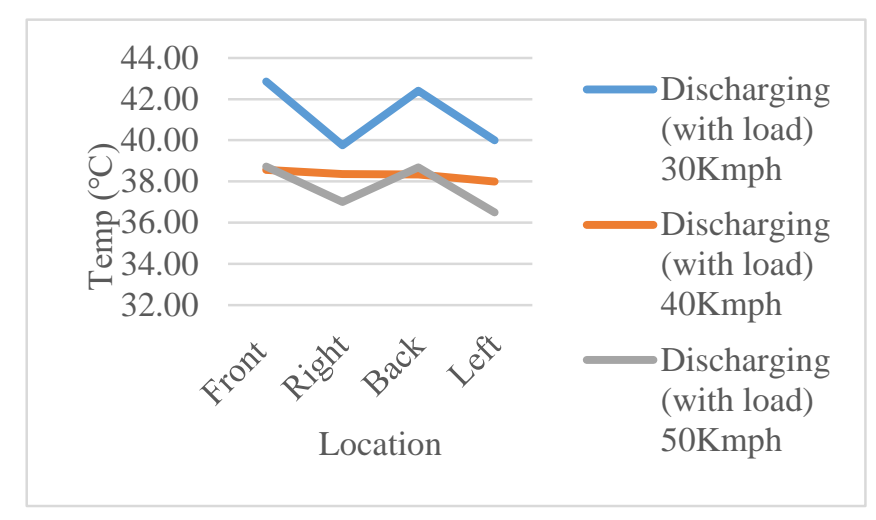

Figure 3(c)

\section{Figure.3 Temperature distribution during day/night Charging(a), discharging with $\operatorname{load}(b)$ without $\operatorname{load}(c)$}

During the discharging test with no load condition, the temperature distribution shows the average temperatures as $31.35^{\circ} \mathrm{C}, 31.31^{\circ} \mathrm{C}$, and $32.02^{\circ} \mathrm{C}$ at 30,40 , and $50 \mathrm{kmph}$. Fig.3(b). At the same time, the average surface temperature distribution with load condition was recorded as $39.44^{\circ} \mathrm{C}, 37.59^{\circ} \mathrm{C}, 36.35^{\circ} \mathrm{C}$ at $30,40,50 \mathrm{kmph}$, respectively.Fig.3(c). Table 2 summarizes the average surface temperatures of different charging and discharging conditions. In comparison, charging in the daytime produces a higher surface temperature than night charging. The front side of the battery shows maximum surface temperature in both day and night charging.

Table 3 Maximum surface temperature location at various Discharging Rates

\begin{tabular}{|c|c|c|c|c|c|c|c|c|}
\hline \multicolumn{9}{|c|}{ Maximum surface Temperature location } \\
\hline \multicolumn{2}{|c|}{ Discharge } & \multicolumn{2}{|l|}{ Front } & Right side & \multicolumn{2}{|l|}{ Back } & \multicolumn{2}{|c|}{ Left side } \\
\hline \multirow{3}{*}{$\begin{array}{l}\text { NO- } \\
\text { LOAD }\end{array}$} & $\begin{array}{l}\text { 30KMP } \\
\text { H }\end{array}$ & \multicolumn{2}{|c|}{ Left Top Corner } & Right Top Corner & \multicolumn{2}{|c|}{ Right Top Corner } & \multicolumn{2}{|c|}{ Left Top Corner } \\
\hline & $\begin{array}{l}\text { 40KMP } \\
\mathrm{H}\end{array}$ & \multicolumn{2}{|c|}{ Left Top Corner } & Middle & \multicolumn{2}{|c|}{ Middle } & \multicolumn{2}{|c|}{ Middle } \\
\hline & $\begin{array}{l}\text { 50KMP } \\
\mathbf{H}\end{array}$ & \multicolumn{2}{|c|}{ Left Bottom Corner } & $\begin{array}{l}\text { Right } \\
\text { Corner }\end{array}$ & $\begin{array}{l}\text { Right } \\
\text { Cornes }\end{array}$ & Bottom & $\begin{array}{l}\text { Left } \\
\text { Corne }\end{array}$ & Bottom \\
\hline \multirow{3}{*}{$\begin{array}{l}\text { AT } \\
\text { LOAD }\end{array}$} & $\begin{array}{l}\text { 30KMP } \\
\mathbf{H}\end{array}$ & $\begin{array}{l}\text { Right } \\
\text { Corner }\end{array}$ & Middle & Left Middle Corner & \multicolumn{2}{|c|}{ Left Middle Corner } & $\begin{array}{l}\text { Right } \\
\text { Corne }\end{array}$ & Middle \\
\hline & $\begin{array}{l}\text { 40KMP } \\
\mathrm{H}\end{array}$ & $\begin{array}{l}\text { Right } \\
\text { Corner }\end{array}$ & Middle & Left Top Corner & \multicolumn{2}{|c|}{ Left Top Corner } & \multicolumn{2}{|c|}{ Right Top Corner } \\
\hline & $\begin{array}{l}\text { 50KMP } \\
\text { H }\end{array}$ & $\begin{array}{l}\text { Right } \\
\text { Corner }\end{array}$ & Bottom & Left Top Corner & \multicolumn{2}{|c|}{ Left Top Corner } & \multicolumn{2}{|c|}{ Right Top Corner } \\
\hline
\end{tabular}


Discharging the battery with E-bike without any load at $30 \mathrm{kmph}, 40 \mathrm{kmph}, 50 \mathrm{kmph}$ the surface temperature reaches the maximum of $33.8^{\circ} \mathrm{C}, 33.6^{\circ} \mathrm{C}$, and $33.9^{\circ} \mathrm{C}$ respectively. Simultaneously with load, the maximum surface temperature reached $47.9^{\circ} \mathrm{C}, 44.2^{\circ} \mathrm{C}$, and $46.7^{\circ} \mathrm{C}$, respectively. There is no significant temperature rise between varying speeds during discharging without load. Still, with limitations, the maximum temperature reaches $30 \mathrm{kmph}$ and gradually decreases at $40 \mathrm{kmph}$ and starts to rise at $50 \mathrm{kmph}$. Table 3 shows the maximum temperatures at different surface views. Fig 4 shows that the time taken for a full discharge of the battery at different conditions decreased with speed increased.
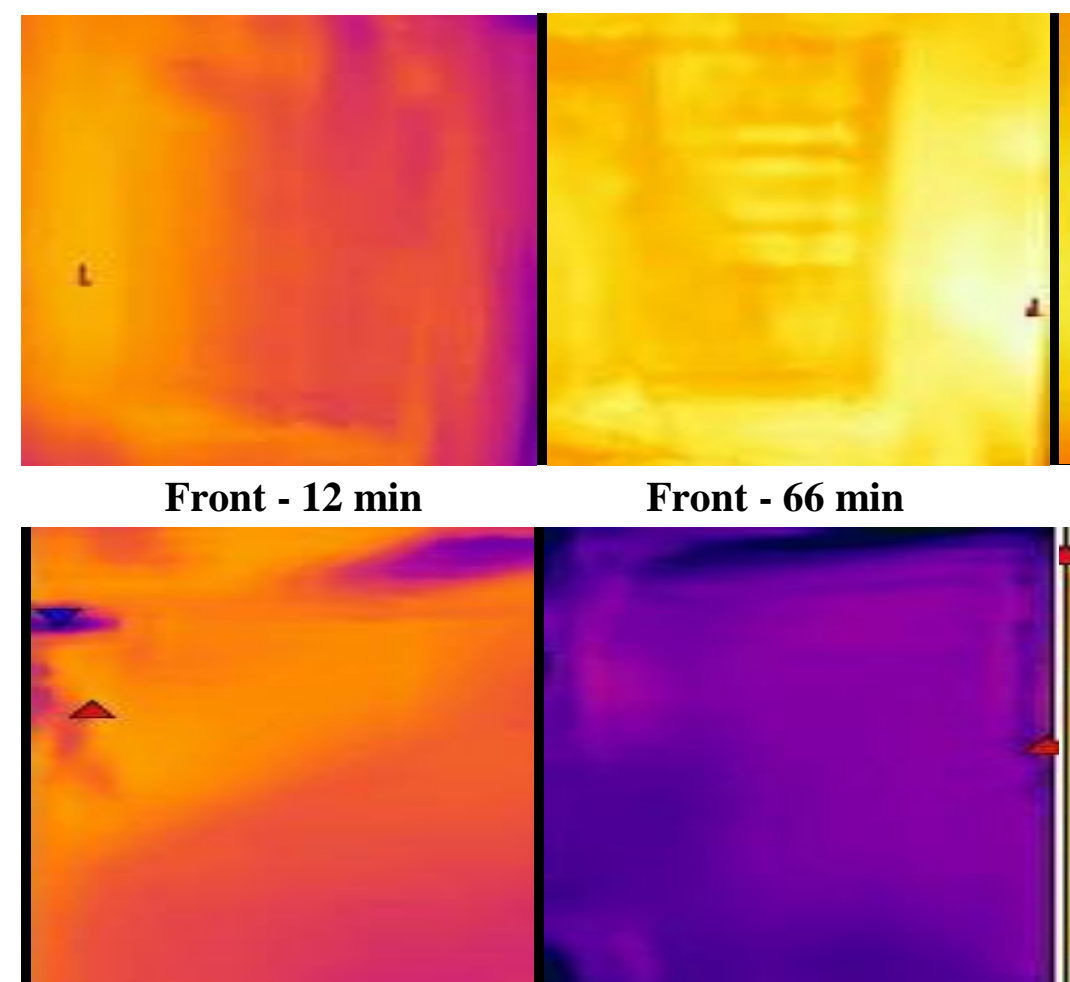

Right - 12 min $\min$

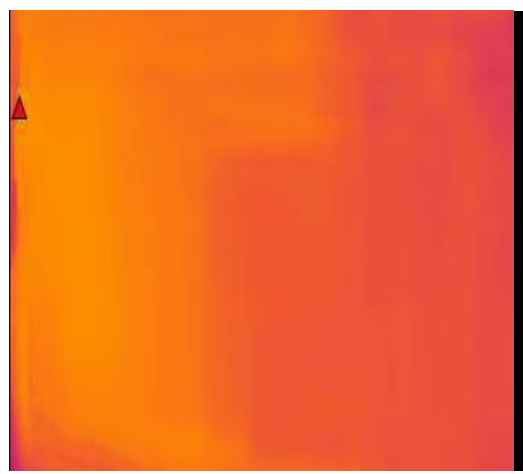

Back - 12 min
Right - 66 min

Right - 102
Front - 102 min
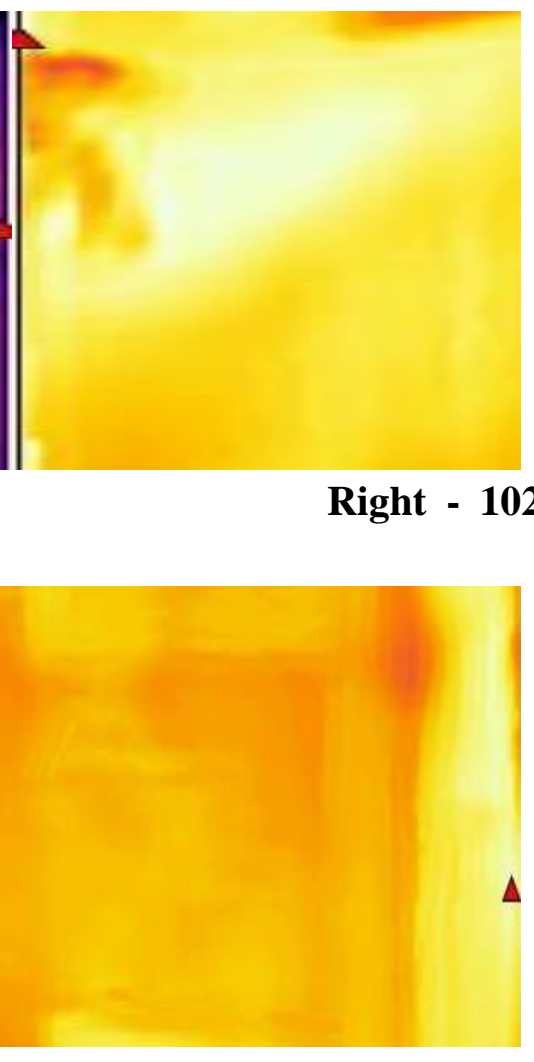

Back - 66 min

Back - 102

$\min$

Fig. 5 (a)Thermal images at a speed of $30 \mathrm{Kmph}$ 


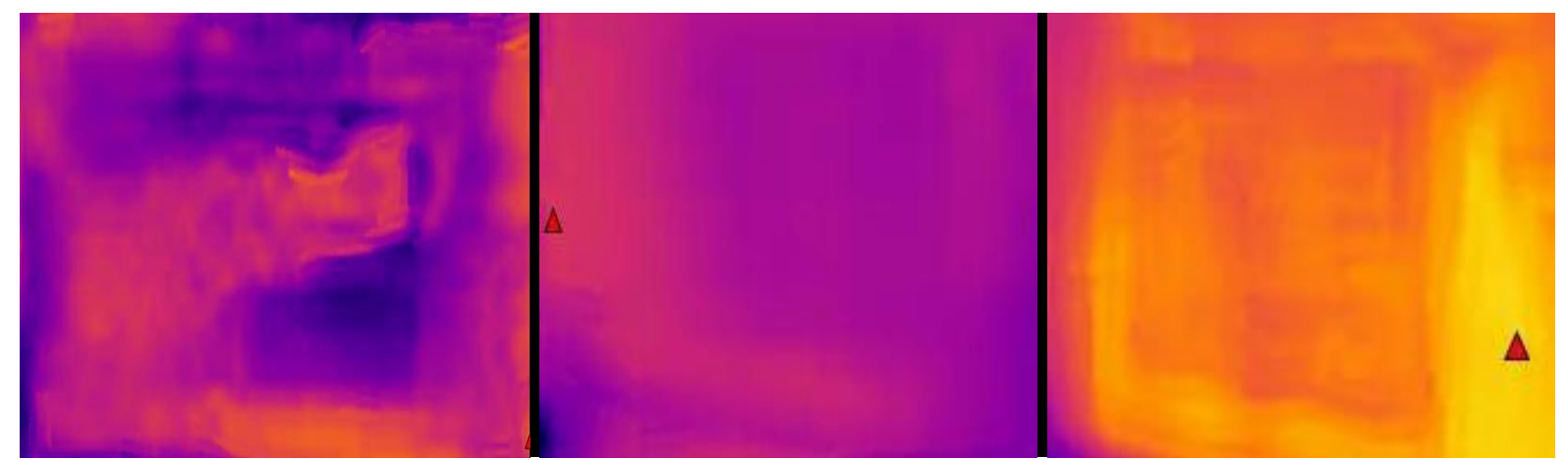

Front - 9 min

Front - 54 min

Front $-94.5 \mathrm{~min}$
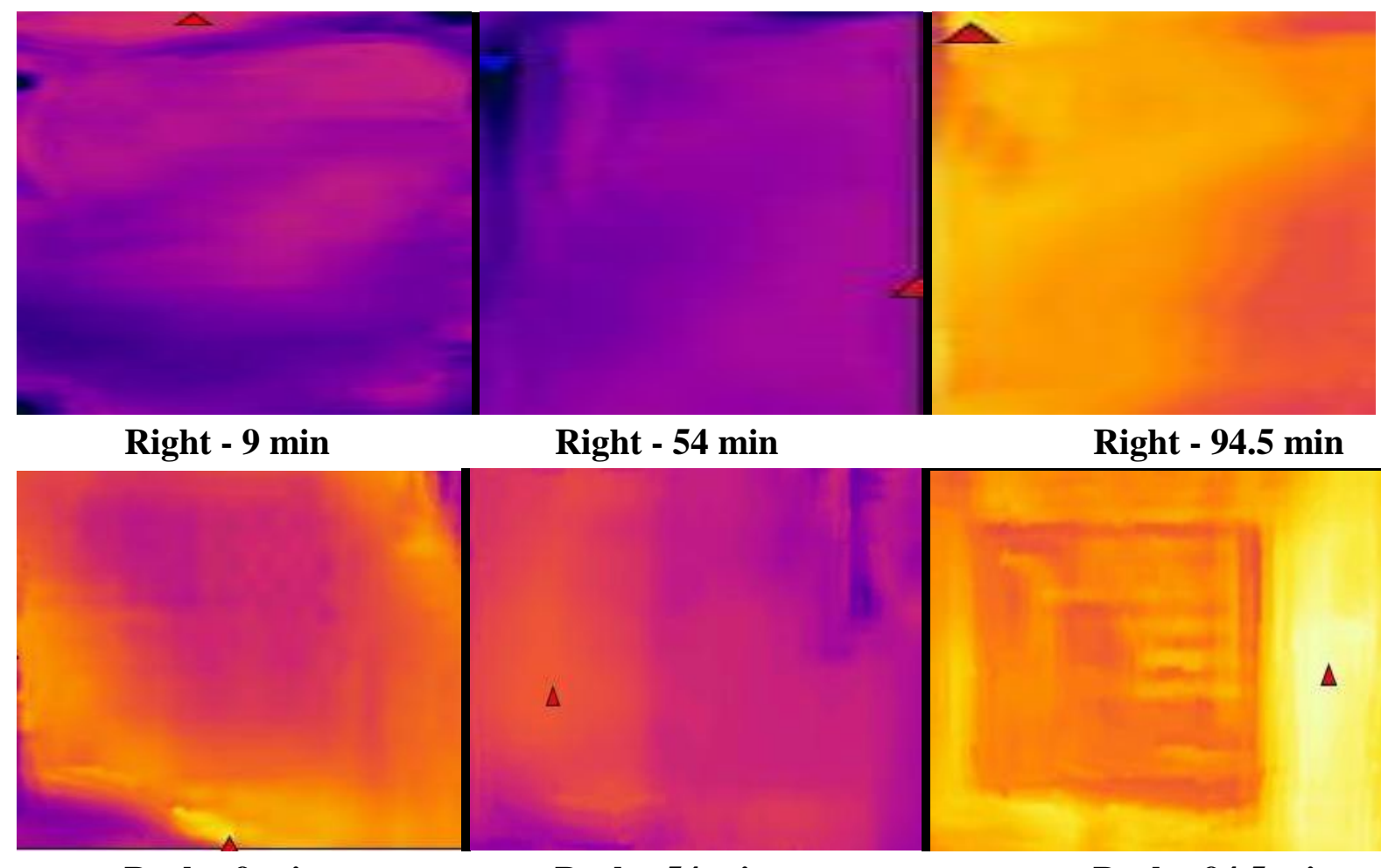

Back - 9 min

Back - 54 min

Back - 94.5 min

Fig. 5 (b)Thermal images at a speed of $40 \mathrm{Kmph}$

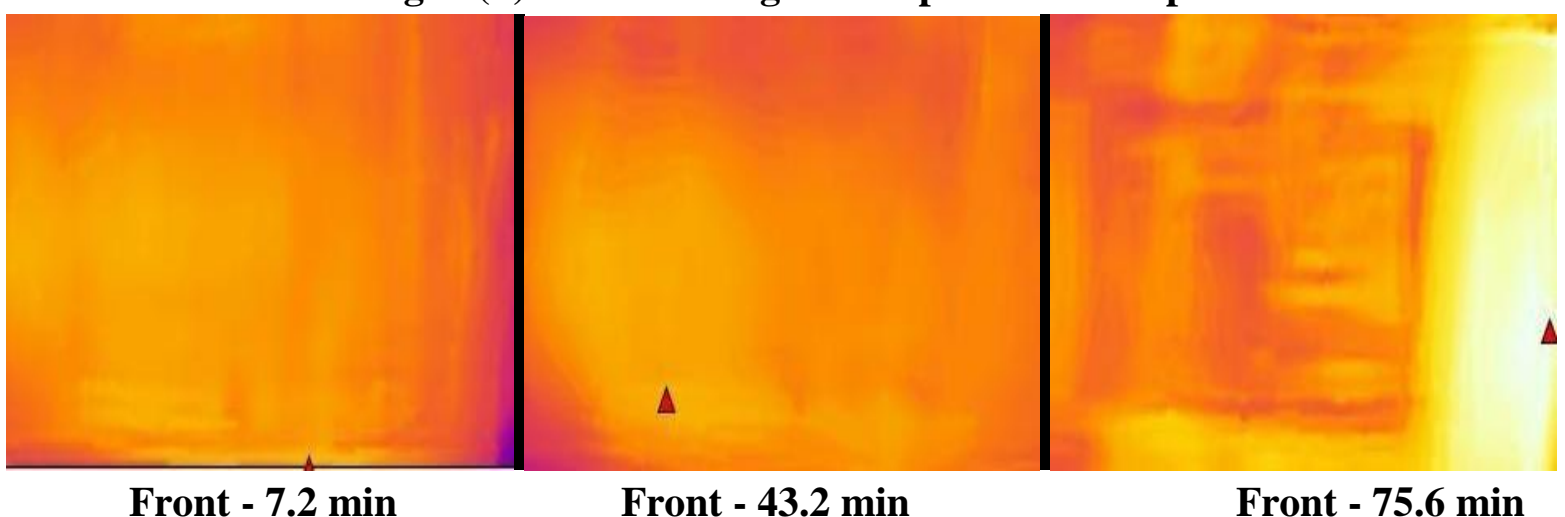




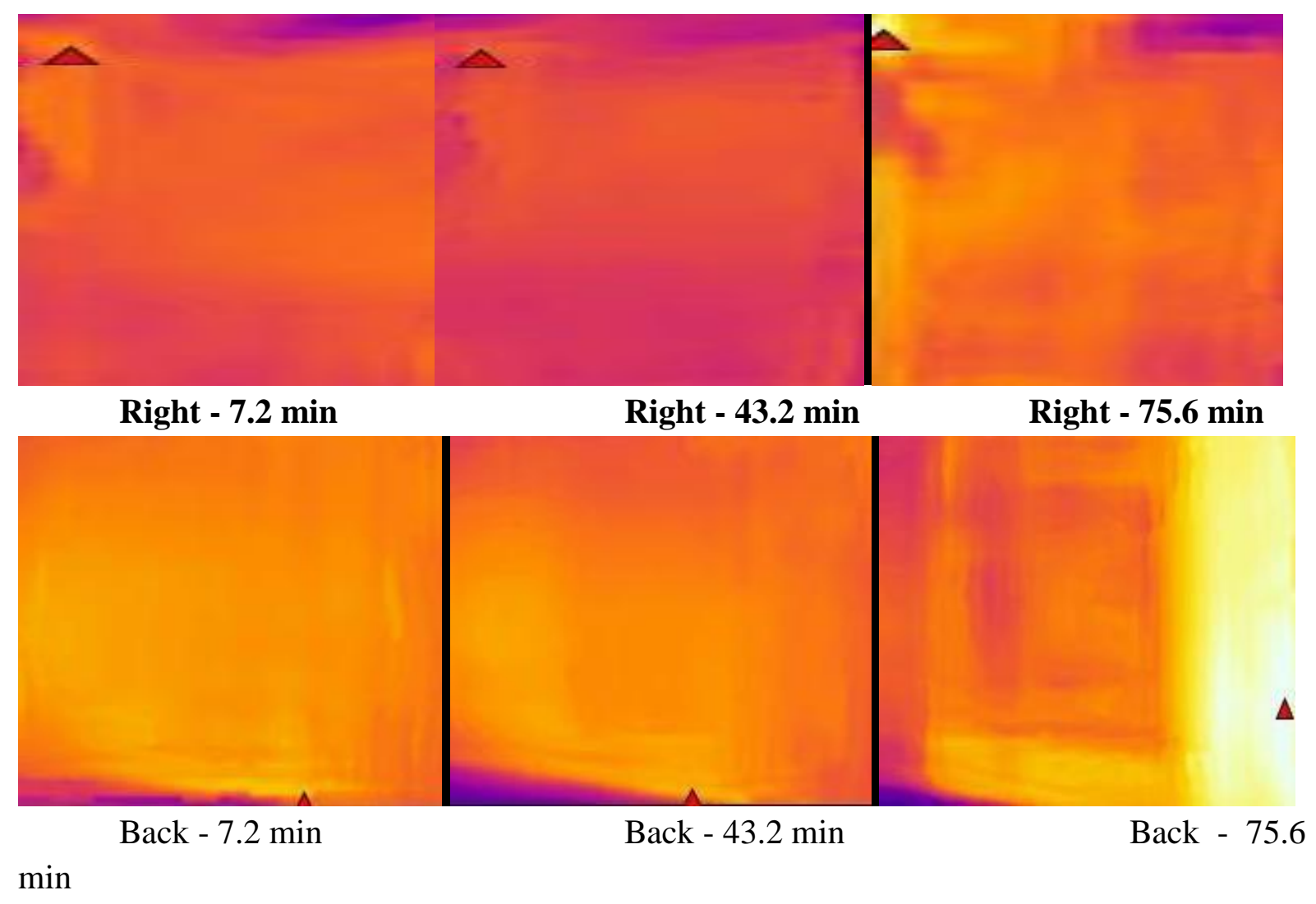

Fig.5. (c) Thermal images at a speed of $50 \mathrm{Kmph}$ Fig. 5. Thermal Images of battery with Load Condition at different speeds

\section{CONCLUSION:}

Thermal behavior of LiFePO4 battery evaluated by measuring its surface temperature distribution during different charging and discharging conditions. Thermal images of the battery with different views front, right, left, back are taken during the entire test. This experiment Evaluates the maximum surface temperature location and spatial surface temperature distribution. The temperature of the battery rises to time while charging. During the discharge test with no load, There is no temperature rise. During discharging with load at $30 \mathrm{kmph}$, the temperature raises to 47 , dropping to 44 at $40 \mathrm{kmph}$. Again rose to 44 until fully discharged. The time taken for full discharge decreases when the speed increases. The battery front shows the maximum surface temperature location in the entire test. These tests proved that thermal imaging is an effective method to evaluate battery thermal behaviors. Moreover, this study's findings will give data supporting battery thermal management system development considering the surface temperature distribution and the increase in temperature. 


\section{REFERENCES}

[1] D. Larcher and J. M. Tarascon, "Towards greener and more sustainable batteries for electrical energy storage," Nature Chemistry, vol. 7, no. 1, pp. 19-29, 2015, doi: 10.1038/nchem.2085.

[2] B. Dunn, H. Kamath, and J. M. Tarascon, "Electrical energy storage for the grid: A battery of choices," Science, vol. 334, no. 6058, pp. 928-935, 2011, doi: 10.1126/science.1212741.

[3] D. Linden and T. B. Reddy, Handbook of batteries, vol. 33, no. 04. 1995. doi: 10.5860/choice.332144.

[4] S. Panchal, I. Dincer, M. Agelin-Chaab, R. Fraser, and M. Fowler, "Thermal modeling and validation of temperature distributions in a prismatic lithium-ion battery at different discharge rates and varying boundary conditions," Applied Thermal Engineering, vol. 96, pp. 190-199, 2016, doi: 10.1016/j.applthermaleng.2015.11.019.

[5] S. Panchal, I. Dincer, M. Agelin-Chaab, R. Fraser, and M. Fowler, "Design and simulation of a lithium-ion battery at large $C$-rates and varying boundary conditions through heat flux distributions," Measurement: Journal of the International Measurement Confederation, vol. 116, pp. 382-390, 2018, doi: 10.1016/j.measurement.2017.11.038.

[6] S. Abada, G. Marlair, A. Lecocq, M. Petit, V. Sauvant-Moynot, and F. Huet, "Safety focused modeling of lithium-ion batteries: A review," Journal of Power Sources, vol. 306, pp. 178-192, 2016, doi: 10.1016/j.jpowsour.2015.11.100.

[7] A. M. Bizeray, S. Zhao, S. R. Duncan, and D. A. Howey, "Lithium-ion battery thermalelectrochemical model-based state estimation using orthogonal collocation and a modified extended Kalman filter," Journal of Power Sources, vol. 296, pp. 400-412, 2015, doi: 10.1016/j.jpowsour.2015.07.019.

[8] S. Goutam, J. M. Timmermans, N. Omar, P. van den Bossche, and J. van Mierlo, "Comparative study of surface temperature behavior of commercial li-ion pouch cells of different chemistries and capacities by infrared thermography, "Energies, vol. 8, no. 8, pp. 8175-8192, 2015, doi: 10.3390/en8088175.

[9] J. B. Robinson et al., "Non-uniform temperature distribution in Li-ion batteries during discharge - A combined thermal imaging, X-ray micro-tomography and electrochemical impedance approach," Journal of Power Sources, vol. 252, pp. 51-57, 2014, doi: 10.1016/j.jpowsour.2013.11.059.

[10] P. Pathmanaban, B. K. Gnanavel, and S. S. Anandan, "Recent application of imaging techniques for fruit quality assessment," Trends in Food Science and Technology, vol. 94, 2019, doi: 10.1016/j.tifs.2019.10.004.

[11] M. F. H. Rani, Z. M. Razlan, A. B. Shahriman, Z. Ibrahim, and W. K. Wan, "Comparative study of surface temperature of lithium-ion polymer cells at different discharging rates by infrared thermography and thermocouple," International Journal of Heat and Mass Transfer, vol. 153, p. 119595, 2020, doi: 10.1016/j.ijheatmasstransfer.2020.119595.

[12] Z. Huang, H. Li, W. Mei, C. Zhao, J. Sun, and Q. Wang, "Thermal Runaway Behavior of Lithium Iron Phosphate Battery During Penetration," Fire Technology, vol. 56, no. 6, pp. 2405-2426, 2020, doi: 10.1007/s10694-020-00967-1.

[13] H. Gao, F. Zhu, and J. Cai, "A Review of Non-destructive Detection for Fruit Quality."

[14] K. Monika, C. Chakraborty, S. Roy, S. Dinda, S. A. Singh, and S. P. Datta, "An improved minichannel based liquid cooling strategy of prismatic LiFePO4 batteries for electric or hybrid vehicles," Journal of Energy Storage, vol. 35, no. January, p. 102301, 2021, doi: 10.1016/j.est.2021.102301. 
